\title{
Protein Lin-28 Homolog B
}

National Cancer Institute

\section{Source}

National Cancer Institute. Protein Lin-28 Homolog B. NCI Thesaurus. Code C101418.

Protein lin-28 homolog B (250 aa, $27 \mathrm{kDa}$ ) is encoded by the human LIN28B gene. This protein plays a role in the degradation of pre-miRNA. 